University of Nebraska - Lincoln

DigitalCommons@University of Nebraska - Lincoln

Faculty Publications: Department of Entomology

2010

\title{
Degree-Day Requirements for Alfalfa Weevil (Coleoptera: Curculionidae) Development in Eastern Nebraska
}

\author{
A. R. Stilwell \\ University of Nebraska-Lincoln, abbyrstilwell@gmail.com \\ Robert J. Wright \\ University of Nebraska, rwright2@unl.edu \\ Thomas E. Hunt \\ University of Nebraska-Lincoln, thunt2@unl.edu \\ Erin E. Blankenship \\ University of Nebraska-Lincoln, erin.blankenship@unl.edu
}

Follow this and additional works at: https://digitalcommons.unl.edu/entomologyfacpub

Part of the Entomology Commons

Stilwell, A. R.; Wright, Robert J.; Hunt, Thomas E.; and Blankenship, Erin E., "Degree-Day Requirements for Alfalfa Weevil (Coleoptera: Curculionidae) Development in Eastern Nebraska" (2010). Faculty

Publications: Department of Entomology. 184.

https://digitalcommons.unl.edu/entomologyfacpub/184

This Article is brought to you for free and open access by the Entomology, Department of at DigitalCommons@University of Nebraska - Lincoln. It has been accepted for inclusion in Faculty Publications: Department of Entomology by an authorized administrator of DigitalCommons@University of Nebraska - Lincoln. 


\title{
Degree-Day Requirements for Alfalfa Weevil (Coleoptera: Curculionidae) Development in Eastern Nebraska
}

\author{
A. R. STILWELL, ${ }^{1}$ R. J. WRIGHT, T. E. HUNT, ${ }^{2}$ AND E. E. BLANKENSHIP ${ }^{3}$ \\ Department of Entomology, 202 Entomology Hall, University of Nebraska-Lincoln, Lincoln, NE 68583-0816
}

Environ. Entomol. 39(1): 202-209 (2010); DOI: 10.1603/EN09048

\begin{abstract}
The alfalfa weevil, Hypera postica (Gyllenhal), is a serious, yet sporadic defoliator of alfalfa, Medicago sativa L., in Nebraska. A 2-yr study was conducted in 2005 and 2006 to test for variation in degree-day requirements by location in eastern Nebraska. Sampling took place along a latitudinal gradient in three regions of eastern Nebraska. Three fields were sampled in each region during the $2 \mathrm{yr}$ of the study. Alfalfa weevil larval degree-day requirements were found to vary by latitude in eastern Nebraska. Alfalfa weevil larvae were discovered in southern regions after fewer developmental degree-days had accumulated than in fields in the northern regions. Alfalfa weevils may be more damaging to alfalfa in southern regions than in northern regions of eastern Nebraska because they emerge earlier relative to alfalfa growth. Management implications of this shift in alfalfa weevil phenology are discussed.
\end{abstract}

KEY WORDS Hypera postica, degree-day, alfalfa management, alfalfa insects

The alfalfa weevil, Hypera postica (Gyllenhal), is the most damaging defoliator of alfalfa, Medicago sativa L,. in Nebraska (Danielson et al. 2006). Damage can be caused by both adult and larval stages, but the majority of damage is caused by larvae. Early-instar alfalfa weevils cause minimal damage, which can be recognized as pinholes in leaf terminals. As larvae increase in size, damage becomes more pronounced and skeletonization of leaves occurs (Danielson et al. 2006). As with many holometabolous insects, $>90 \%$ of feeding damage is caused by late instars (Koehler and Pimentel 1973). The first crop of alfalfa is most susceptible to serious feeding injury (Liu and Fick 1975). Growth of the second crop can be delayed under heavy infestations (Fick 1976), but plant development and forage quality are less affected at this time (Giles et al. 1999).

Two strains of the alfalfa weevil, the eastern and western strains, are found in Nebraska (Keith et al. 1977; Manglitz et al. 1981a,b). The western strain was introduced into the Salt Lake City, UT, area in 1904 (Hamlin et al. 1949), and the eastern strain was introduced into Maryland in 1952 (White et al. 1972, Erney et al. 1996).

The alfalfa weevil is present in all 48 states of the continental United States (Giles et al. 1999, NAPISCAPS 2003). Typically, one generation occurs per year (Berberet and Hutchison 1994, Brewer and Hoff 2002) and adults generally overwinter in protected

\footnotetext{
${ }^{1}$ Corresponding author, e-mail: abbyrstilwell@gmail.com.

${ }^{2}$ Haskell Agricultural Laboratory, 57905866 Rd., University of Nebraska-Lincoln, Concord, NE 68728.

${ }^{3}$ Department of Statistics, 340 Hardin Hall, University of NebraskaLincoln, Lincoln, NE 68583-0963.
}

areas near alfalfa fields (Yakhontov 1974, Danielson et al. 2006). The phenology of the alfalfa weevil in the United States varies with latitude (Peterson and Meyer 1995).

Fall and winter temperatures in northern regions of the United States often are too low to allow for extensive oviposition or embryonic development to occur, and accordingly, eggs laid in the fall and winter in these regions do not contribute significantly to larval populations in the spring (Stark et al. 1994). Northern regions also have temperatures that are below the lower lethal limit of $1.7^{\circ} \mathrm{C}$ for oviposition, and mortality of eggs is a common occurrence (LeCato and Pienkowski 1972, Stark et al. 1994). Effective egglaying begins, consequently, at the onset of spring alfalfa growth in northern regions (Stark et al. 1994) such as Wisconsin (Litsinger and Apple 1973).

Southern regions, however, may experience milder winters, resulting in eggs being laid earlier and alfalfa weevils surviving winter conditions more readily (Stark et al. 1994). Alfalfa weevils inhabiting southern regions, such as Oklahoma and southern California, have more temporal variability in oviposition and may deposit a greater number of eggs from late November to mid-March (Stark et al. 1993, DeGooyer et al. 1996), which may result in earlier alfalfa weevil egg hatch in spring.

In intermediate regions, such as Illinois, Ohio, and Nebraska, weather conditions, which are greatly affected by latitude, may influence the number of alfalfa weevil eggs laid and their survival in fall and winter months (DeGooyer et al. 1996). Populations found in intermediate regions show a pattern of increased fall 
oviposition and winter survival with declining latitude (Roberts et al. 1970, Peterson and Meyer 1995, DeGooyer et al. 1996).

Insect development is strongly correlated with temperature and time (Higley et al. 1986, Pedigo and Zeiss 1996). The rate of development increases with increasing temperature, forming an s-shape curve. The curve begins with the developmental minimum, the top of the curve represents the developmental maximum threshold, and the amount of heat required between maximum and minimum developmental thresholds is calculated in degree-days (Higley et al. 1986, Pedigo and Zeiss 1996, Gibson 2001).

Models that use this knowledge are able to predict insect emergence and stage emergence (Higley et al. 1986, Berberet and Hutchinson 1994, Pedigo and Zeiss 1996). A model has been developed to calculate developmental degree-days for the alfalfa weevil using a developmental minimum threshold of $9^{\circ} \mathrm{C}\left(48^{\circ} \mathrm{F}\right)$ (Koehler and Gyrisco 1961; Litsinger and Apple 1973; Stark et al. 1993, 1994; DeGooyer et al. 1996; Kuhar et al. 2000). Because variable oviposition rates and egg survival during fall and winter can occur in intermediate regions such as Nebraska and can lead to differences in the timing of egg hatch and larval populations the following spring, predicted developmental degree-day values may vary by latitude (Roberts et al. 1970). Recent observations in Nebraska suggest alfalfa weevil phenology is inconsistent with published accounts (Seymour and Jarvi 2002).

The objective of this study was to compare alfalfa weevil developmental degree-day requirements in three distinct geographical regions in Nebraska, which varied by latitude. Information obtained in this study will be useful for making more accurate pest management decisions in different regions in eastern $\mathrm{Ne}$ braska and explain observed differences in weevil occurrence in these regions.

\section{Materials and Methods}

Field Locations. Alfalfa weevil populations were sampled in nine alfalfa fields in eastern Nebraska in the spring of 2005 and 2006. Three fields were sampled in each of three regions: southern (2005: $40^{\circ} 18.049^{\prime} \mathrm{N}$, $96^{\circ} 51.631^{\prime} \mathrm{W} ; 40^{\circ} 17.355^{\prime} \mathrm{N}, 96^{\circ} 56.122^{\prime} \mathrm{W} ; 40^{\circ} 15.762^{\prime} \mathrm{N}$, 96 $55.786^{\prime} \quad \mathrm{W} ; 2006: 40^{\circ} 18.049^{\prime} \mathrm{N}, 96^{\circ} 51.631^{\prime} \mathrm{W}$; $40^{\circ} 17.126^{\prime} \mathrm{N}, 96^{\circ} 56.026^{\prime} \mathrm{W}, 40^{\circ} 15.779^{\prime} \mathrm{N}, 96^{\circ} 51.188^{\prime} \mathrm{W}$; elevation, $395 \mathrm{~m}$ ), central (2005: $41^{\circ} 09.700^{\prime} \mathrm{N}$, $96^{\circ} 29.790^{\prime} \mathrm{W} ; 41^{\circ} 10.116^{\prime} \mathrm{N}, 96^{\circ} 29.130^{\prime} \mathrm{W} ; 41^{\circ} 10.349^{\prime} \mathrm{N}$, $96^{\circ} 28.691^{\prime} \quad \mathrm{W} ;$ 2006: $41^{\circ} 09.700^{\prime} \mathrm{N}, 96^{\circ} 29.790^{\prime} \mathrm{W}$; $41^{\circ} 10.116^{\prime} \mathrm{N}, 96^{\circ} 29.130^{\prime} \mathrm{W} ; 41^{\circ} 09.472^{\prime} \mathrm{N}, 96^{\circ} 29.692^{\prime} \mathrm{W}$; elevation, $351 \mathrm{~m}$ ), and northern (2005: $42^{\circ} 37.569^{\prime} \mathrm{N}$, $97^{\circ} 47.965^{\prime} \mathrm{W} ; 42^{\circ} 38.016^{\prime} \mathrm{N}, 97^{\circ} 46.369^{\prime} \mathrm{W} ; 42^{\circ} 37.571^{\prime} \mathrm{N}$, $97^{\circ} 48.742^{\prime} \mathrm{W}$; 2006: $42^{\circ} 37.569^{\prime} \mathrm{N}, 97^{\circ} 47.965^{\prime} \mathrm{W}$; $42^{\circ} 38.016^{\prime} \mathrm{N}, 97^{\circ} 46.369^{\prime} \mathrm{W} ; 42^{\circ} 40.524^{\prime} \mathrm{N}, 97^{\circ} 45.377^{\prime} \mathrm{W}$; elevation, $497 \mathrm{~m}$ ). Alfalfa was produced according to standard agronomic practices, and field stands ranged from 2 to $5 \mathrm{yr}$ in age. Insecticides were not applied in any field, except one in the northern region used in 2005. Sampling was discontinued after insecticide application.
Sampling Alfalfa Weevil Larval Populations. Informal sampling began in early spring. On observation of the first larva, sampling protocols were initiated. Sampling occurred in each of the nine fields approximately every $7 \mathrm{~d}$, unless rainfall occurred. After a rain event, sampling started when precipitation ceased, usually within 1 or $2 \mathrm{~d}$. To avoid dew caused by humidity, all fields were sampled after 1000 hours.

Each field was visually divided into four quadrants, and each quadrant was sampled, for a total of four samples per field. A U-shaped pattern was followed in the field, varying the location of sampling each week. The location for sampling within each quadrant was selected randomly, avoiding the field edge by at least $3 \mathrm{~m}$ (Buntin 1994). To avoid preferential sampling, the location to start sampling in each quadrant was selected from a distance.

Five stems were selected in each quadrant, shaken roughly into a bucket, and saved in another bag. This process was repeated until 25 stems had been obtained from a quadrant. Stems were selected randomly by choosing each stem near the ground without observing its size or condition, and stems were removed using the finger-shear method (Higgins et al. 1991), keeping the top of each stem as steady as possible. A total of 100 stems were collected in each field, at each sampling location.

The density of alfalfa weevil larvae in fields located in northern regions of Nebraska was very low in 2005. Because numbers were low, 2 wk after formal sampling began the sample size was increased to 100 stems in each quadrant for fields located in northern regions of eastern Nebraska. The procedure for selecting stems and locations remained consistent with other regions. Stem samples of 100 stems were also taken in northern fields in 2006, beginning with the first formal sampling date.

Shake-bucket and stem sampling continued until the first cutting and then resumed $\sim 1 \mathrm{wk}$ after harvest, when stems were at least $10 \mathrm{~cm}$ (4 in) tall. Sampling was discontinued when alfalfa weevil larvae were no longer present in samples obtained from each field.

Laboratory Analysis. In the laboratory, stems were visually inspected for additional larvae missed in the shake-bucket method. The number of larvae found in the shake-bucket was combined with the number found and removed from the corresponding stem sample to form an absolute sample of the density of alfalfa weevil larvae.

Number of first-, second-, third-, and fourth-instar alfalfa weevils was determined by measuring the width of the head capsule (Hamlin et al. 1949) with an ocular micrometer and dissecting microscope. After an adequate number of larvae were separated using this method, differentiation was determined visually with the aid of a magnifying lamp (Bartell and Roberts 1974) and a reference collection of previously measured larvae.

Temperature Monitoring. Temperature data were obtained from the High Plains Regional Climate Center (HPRCC) located at the University of NebraskaLincoln (HPRCC 2006). Daily maximum and mini- 
mum temperature data were obtained from HPRCC for three locations (southern: $40^{\circ} 18.00^{\prime} \mathrm{N}, 96^{\circ} 45.00^{\prime} \mathrm{W}$; central: $41^{\circ} 09.00^{\prime} \mathrm{N}, 96^{\circ} 24.00^{\prime} \mathrm{W}$; northern: $42^{\circ} 27.00^{\prime}$ $\left.\mathrm{N}, 97^{\circ} 54.00 \mathrm{~W}\right)$. Locations were chosen by using the closest weather station to each set of fields. The weather stations that were chosen are the most reliable source of temperature data for crop managers and farmers. The distance between fields and weather stations ranged from 7.0 to $27.8 \mathrm{~km}$ (4.3-17.3 miles) (Stilwell 2006). The weather station originally selected for temperature data retrieval for northern fields was much closer to sampled fields; however, this weather station was no longer providing temperature data and therefore the next closest weather station, $27.8 \mathrm{~km}$ distant, was used. Weather data were obtained beginning 1 January 2005 and 2006.

Developmental Degree-Day Calculations. Developmental degree-days were calculated using a minimum developmental threshold of $9^{\circ} \mathrm{C}$ (Koehler and Gyrisco 1961; Litsinger and Apple 1973; Stark et al. 1993, 1994; DeGooyer et al. 1996; Kuhar et al. 2000) and were calculated beginning 1 January of each year.

The computer program DEGDAY Version 1.2 was used to perform developmental degree-day calculations for the alfalfa weevil (Higley et al. 1986). Developmental degree-days were calculated using the sine wave method. The sine wave method assumes the daily temperature cycle takes the form of a sine wave, and the wave is produced over a 24 -h period using maximum and minimum temperatures from that day. The area produced under the temperature curve, and above the base temperature, represents the degreeday accumulations during $1 \mathrm{~d}$. This method is more accurate than the rectangle or triangle method when minimum temperatures recorded for the day are below the developmental minimum temperature for the insect (Herms 2006).

Statistical Analysis. A nonlinear model was used to calculate differences in developmental degree-day accumulations by location and instar. A logistic curve was used to model the response of larvae as a function of growing degree-days. The formula used for the logistic curve is as follows: Percent accumulated $=(\mathrm{a}+$ $\mathrm{a} 1 * \operatorname{loc} 1+\mathrm{a} 2 * \operatorname{loc} 2) /\{1+\exp [(\mathrm{b}+\mathrm{b} 1+\operatorname{loc} 1+\mathrm{b} 2+$ loc 2$)+(\mathrm{c}+\mathrm{c} 1+\operatorname{loc} 1+\mathrm{c} 2+\operatorname{loc} 2) *$ acdd $]\}$, where a is the upper asymptote and the infection point occurs at $\mathrm{X}=\mathrm{b} / \mathrm{c}$ and $\mathrm{Y}=\mathrm{a} / 2$. The variables $\mathrm{a}, \mathrm{b}$, and $\mathrm{c}$ refer to southern locations, al, b1, c1, and loc1 refer to central locations, and $\mathrm{a} 2, \mathrm{~b} 2, \mathrm{c} 2$, and loc2 refer to northern locations. The model was fit with SAS software using PROC NLMIXED (SAS Institute 2001).

Calculations were made separately for each year, and comparisons were made between each location (northern, central, and southern) and for each instar. Estimates of inflection point (the time when the rate of emergence is at its maximum and $50 \%$ of alfalfa weevils have emerged), time before linear emergence (the number of degree-days that passed before alfalfa weevil larvae began emerging in a linear fashion), days of linear emergence (the number of degree-days when alfalfa weevil larvae emerged in a linear fashion), emergence rate (the speed at which

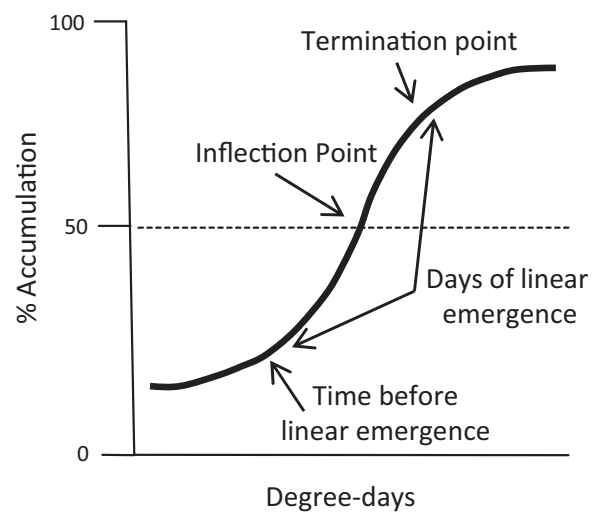

Fig. 1. Generic model of alfalfa weevil phenological development depicting locations on the curve where statistical information was derived.

alfalfa weevil larvae emerged), and termination point (the time when linear emergence ended) were calculated (Fig. 1).

\section{Results}

The number of accumulated developmental degree-days was recorded for the first observation of each instar in 2005 and 2006 (Table 1). First-, second-, and third-instar alfalfa weevils were observed to emerge with fewer accumulated degree-days in southern regions compared with northern regions for both years.

Degree-day accumulations were plotted against the accumulated percentage of alfalfa weevil first, second, and third instars collected (Fig. 2), and statistics were calculated for each instar, location, and year.

\section{First-Instar Alfalfa Weevils}

Inflection Point. In 2005, the inflection point, or time to maximum emergence, for first instars occurred at 240 accumulated developmental degree-days in northern regions $(t$ value $=38.92 ; \mathrm{df}=37 ; P \leq 0.0001)$, $197 \mathrm{DD}$ in central regions $(t$ value $=49.80 ; \mathrm{df}=37 ; P \leq$ $0.0001)$, and $196 \mathrm{DD}$ in southern regions $(t$ value $=$ 93.60; $\mathrm{df}=37 ; P \leq 0.0001)$. In 2006, the inflection point for first instars occurred at 196 accumulated DD in northern regions $(t$ value $=57.36 ; \mathrm{df}=21 ; P \leq 0.0001)$, 223 accumulated DD at central regions ( $t$ value $=$

Table 1. Developmental degree-day accumulations at first observation of alfalfa weevil larvae by region

\begin{tabular}{llccc}
\hline \hline Year & Region & First instar & Second instar & Third instar \\
\hline 2005 & Northern & 139 & 139 & 203 \\
2005 & Central & 126 & 126 & 126 \\
2005 & Southern & 123 & 123 & 189 \\
2006 & Northern & 171 & 181 & 209 \\
2006 & Central & 178 & 178 & 178 \\
2006 & Southern & 142 & 142 & 199 \\
\hline
\end{tabular}

Accumulated developmental degree-days were taken from raw data and were not analyzed statistically. 

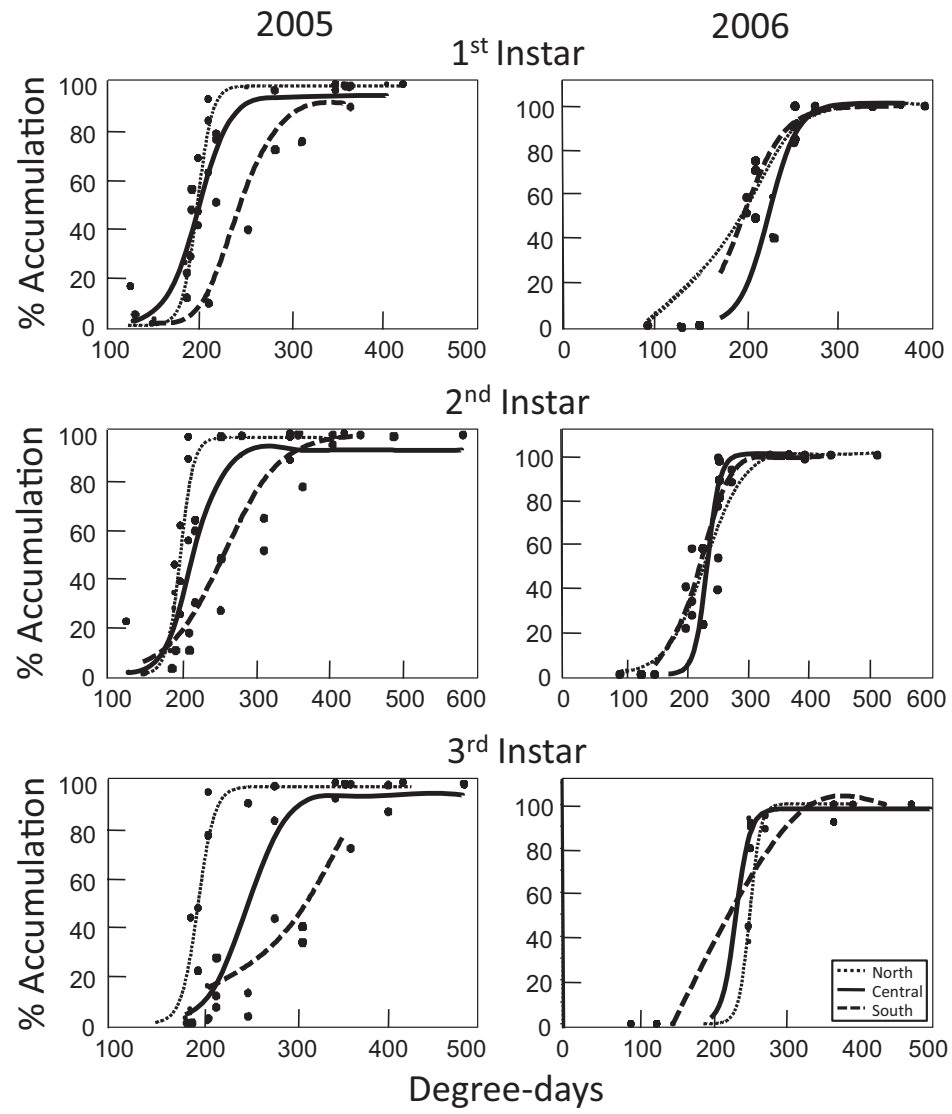

Fig. 2. Phenological development of alfalfa weevil larvae for first, second, and third instars in 2005 and 2006 with curves denoting each region (northern, central, southern).

77.63; df $=21 ; P \leq 0.0001$ ), and 195 accumulated DD at southern regions $(t$ value $=32.17 ; \mathrm{df}=21 ; P \leq$ $0.0001)$. Inflection point was not statistically different between regions for first instars in either year.

Time Before Linear Emergence. The time to linear emergence was significantly different for first instars when comparing northern regions to southern regions in both 2005 and 2006. In 2005, northern regions required 41 more developmental degree-days before first instar emergence than central regions $(t$ value $=$ -3.05 ; $\mathrm{df}=42 ; P=0.0039)$, and 24 more developmental degree-days than southern regions $(t$ value $=$ $2.04 ; \mathrm{df}=42 ; P=0.0478)$. In 2006, northern regions required 57 more degree-days before linear emergence compared with southern regions $(t$ value $=5.33$; $\mathrm{df}=21 ; P \leq 0.0001)$ and central regions required 62 more degree-days before emergence compared with southern regions $(t$ value $=5.11 ; \mathrm{df}=21 ; P \leq 0.0001)$.

Days of Linear Emergence. The length of linear emergence for first instars in 2005 was longer in northern regions than southern regions by $28 \mathrm{DD}(t$ value $=$ $1.30 ; \mathrm{df}=42 ; P=0.1992)$ and longer in central regions than southern regions by $38 \mathrm{DD}(t$ value $=1.71 ; \mathrm{df}=$ $42 ; P=0.0951)$ but not significantly. Days of linear emergence were not significantly different between northern and central regions for first instars in 2005. In
2006, length of linear emergence for first instars was greater in southern regions than central regions by 60 DD $(t$ value $=-2.56 ; \mathrm{df}=21 ; P=0.0181)$ and greater than northern regions by $91 \mathrm{DD}(t$ value $=-4.39 ; \mathrm{df}=$ $21 ; P=0.0003)$. Central regions had 32 more degreedays of linear emergence than northern regions $(t$ value $=3.345 ; \mathrm{df}=21 ; P=0.0031$ ).

Emergence Rate. Emergence rates for first instars in 2005 for northern and central versus southern regions were not significantly different, but rates were greater in southern regions than in both northern $(t$ value $=-1.44 ; \mathrm{df}=42 ; P=0.1584)$ and central $(t$ value $=-1.63 ; \mathrm{df}=42 ; P=0.1098)$ regions. Emergence rate was not significantly different between northern and central regions for first instars. In 2006, the rate of emergence was 5 DD greater in northern regions compared with central regions ( $t$ value $=-9.52 ; \mathrm{df}=21 ; P \leq 0.0001)$ and 6 DD greater in southern versus central regions $(t$ value $=33.29 ; \mathrm{df}=21 ; P \leq 0.0001)$. Central regions had a 1 DD greater emergence rate than southern regions $(t$ value $=2.72 ; \mathrm{df}=21 ; P=0.0127)$.

Termination Point. In 2005, the termination point for first instars occurred after less accumulated degree-days in central regions compared with northern regions by $31 \mathrm{DD}$ and approached significance $(t$ 
value $=-2.01 ; \mathrm{df}=42 ; P=0.0508)$. The termination point occurred after less accumulated degree-days in southern regions compared with central regions by 21 $\mathrm{DD}$, which approached significance $(t$ value $=1.64$; $\mathrm{df}=42 ; P=0.1084)$. The termination point occurred after less accumulated degree-days in southern regions compared with northern regions by $52 \mathrm{DD}(t$ value $=11.78 ; \mathrm{df}=42 ; P \leq 0.0001)$. In 2006, the termination point for northern regions was $37 \mathrm{DD}$ later than central regions $(t$ value $=5.0499 ; \mathrm{df}=21$; $P \leq 0.0001)$ and $35 \mathrm{DD}$ later than southern regions $(t$ value $=-2.87 ; \mathrm{df}=21 ; P=0.0091)$. The termination point was not statistically different between central and northern regions.

\section{Second-Instar Alfalfa Weevils}

Inflection Point. In 2005, the inflection point, or time to maximum emergence, for second-instar alfalfa weevils occurred at $256 \mathrm{DD}$ in northern regions $(t$ value $=12.08 ; \mathrm{df}=39 ; P \leq 0.0001), 212 \mathrm{DD}$ in central regions ( $t$ value $=30.46 ; \mathrm{df}=39 ; P \leq 0.0001)$, and 197 $\mathrm{DD}$ in southern regions $(t$ value $=68.99 ; \mathrm{df}=39 ; P=$ $\leq 0.0001)$. In 2006, the inflection point of second instars was calculated to be $222 \mathrm{DD}$ in northern regions $(t$ value $=29.21 ; \mathrm{df}=25 ; P \leq 0.0001), 234 \mathrm{DD}$ in central regions $(t$ value $=67.32 ; \mathrm{df}=25 ; P \leq 0.0001)$, and $228 \mathrm{DD}$ in southern regions $(t$ value $=24.38 ; \mathrm{df}=$ $25 ; P \leq 0.0001)$. Inflection point was not statistically different between regions for second instars in either year.

Time Before Linear Emergence. For second instars in 2005 , the time before linear emergence occurred at 180 accumulated developmental degree-days in northern regions $(t$ value $=11.70 ; \mathrm{df}=39 ; P \leq 0.0001)$, $176 \mathrm{DD}$ in central regions $(t$ value $=16.92 ; \mathrm{df}=39 ; P \leq$ $0.0001)$, and $179 \mathrm{DD}$ in southern regions $(t$ value $=$ 21.56 ; $\mathrm{df}=39 ; P \leq 0.0001$ ), but there were no significant differences between regions. Central regions in 2006 required 36 more developmental degree-days before linear emergence than northern regions $(t$ value $=2.80 ; \mathrm{df}=25 ; P=0.0097)$ and 41 more degreedays before linear emergence than southern regions $(t$ value $=2.28 ; \mathrm{df}=25 ; P=0.0315)$. There was no significant difference between northern and southern regions.

Days of Linear Emergence. The length of linear emergence for second instars in 2005 was not significantly different between regions. In 2006, southern regions had 80 more degree-days of linear emergence than central regions in $2006(t$ value $=-2.60 ; \mathrm{df}=25$; $P=0.0153$ ), and northern regions had 51 more degreedays of linear emergence than central regions $(t$ value $=-1.91 ; \mathrm{df}=25 ; P=0.0673)$ and approached significance. There was no significant difference in days of linear emergence between northern and southern regions for second instars in 2006.

Emergence Rate. There were no significant differences in emergence rate between regions for second instars in 2005. In 2006, the emergence rate for second instars occurred in central regions after one less degree-day than southern regions $(t$ value $=2.13 ; \mathrm{df}=$
25; $P=0.0430)$. The emergence rate for northern regions was 6 DD greater compared with central regions $(t$ value $=1.75 ; \mathrm{df}=25 ; P=0.0927)$.

Termination Point. In 2005, the termination point for second-instar larvae occurred after less accumulated degree-days in central regions compared with southern regions by $46 \mathrm{DD}$ in $2005(t$ value $=1.71 ; \mathrm{df}=$ $42 ; P=0.0945)$ and approached significance; however, in 2006, second instars in southern regions terminated after less accumulated degree-days compared with central regions by $39 \mathrm{DD}(t$ value $=-1.08 ; \mathrm{df}=25 ; P=$ $0.0339)$.

\section{Third-Instar Alfalfa Weevils}

Inflection Point. The inflection point, or time to maximum emergence, for third instars in 2005 occurred at $367 \mathrm{DD}$ in northern regions $(t$ value $=5.35$; $\mathrm{df}=30 ; P \leq 0.0001), 250 \mathrm{DD}$ in central regions $(t$ value $=22.28 ; \mathrm{df}=30 ; P \leq 0.0001)$, and $200 \mathrm{DD}$ in southern regions $(t$ value $=83.13 ; \mathrm{df}=30 ; P \leq 0.0001)$. Maximum emergence for third instars in 2006 occurred at $239 \mathrm{DD}$ in northern regions $(t$ value $=34.53$; $\mathrm{df}=16 ; P \leq 0.0001), 234 \mathrm{DD}$ in central regions $(t$ value $=69.27 ; \mathrm{df}=16 ; P \leq 0.0001)$, and $254 \mathrm{DD}$ in southern regions $(t$ value $=80.2 ; \mathrm{df}=16 ; P \leq 0.0001)$. Inflection point was not statistically different between regions for third instars in either year.

Time Before Linear Emergence. The time before linear emergence for third instars in 2005 was estimated to be $208 \mathrm{DD}$ in central regions $(t$ value $=14.05$; $\mathrm{df}=30 ; P \leq 0.0001)$ and $187 \mathrm{DD}$ in southern regions $(t$ value $=30.22 ; \mathrm{df}=30 ; P \leq 0.0001)$, but the difference in degree-days was not significant $(t=1.22 ; \mathrm{df}=$ $33 ; P=0.2306)$. The time to linear emergence in 2006 occurred at $197 \mathrm{DD}$ in northern regions $(t$ value $=$ $17.25 ; \mathrm{df}=16 ; P \leq 0.0001), 215 \mathrm{DD}$ in central regions $(t$ value $=40.42 ; \mathrm{df}=16 ; P \leq 0.0001)$, and $239 \mathrm{DD}$ in southern regions $(t$ value $=31.91 ; \mathrm{df}=16 ; P \leq 0.0001)$. Differences between regions, however, were not significant.

Days of Linear Emergence. Third instars in central regions had more degree-days of linear emergence than southern regions in 2005 and approached significance $(t$ value $=1.93 ; \mathrm{df}=33 ; P=0.0626)$. In 2006, second instars in the southern regions had more degree-days of linear emergence than in northern regions by $11 \mathrm{DD}(t$ value $=-1.52 ; \mathrm{df}=16 ; P=0.1481)$ but not significantly. There were no significant differences in days of linear emergence between northern and central regions or central and southern regions for third instars in 2006.

Emergence Rate. Emergence rates for third instars were not significantly different between regions in 2005. In 2006, the emergence rate was 2 DD more in northern regions compared with central regions $(t$ value $=-10.88 ; \mathrm{df}=16 ; P \leq 0.0001)$ and $1 \mathrm{DD}$ more in northern regions compared with southern regions $(t$ value $=5.61 ; \mathrm{df}=16 ; P \leq 0.0001)$. Southern regions had a faster rate of emergence than central regions by $1 \mathrm{DD}(t$ value $=-5.36 ; \mathrm{df}=16 ; P \leq 0.0001)$. 
Termination Point. In 2005, third instars in central regions approached the termination point $82 \mathrm{DD}$ before southern regions $(t$ value $=4.28 ; \mathrm{df}=33 ; \mathrm{P}=$ $0.002)$. In 2006, third instars in southern regions terminated earlier than both central $(t$ value $=-1.56$; $\mathrm{df}=16 ; P=0.1376)$ and northern regions $(t$ value $=$ $-1.67 ; \mathrm{df}=16 ; P=0.1135)$ by 17 and $10 \mathrm{DD}$, respectively, and approached significance. There was no significant difference for third instars between central and northern regions in 2006.

\section{Discussion}

The inflection point, or the time to maximum emergence, occurred after more accumulated degree-days in northern regions than central regions for all instars in 2005. In 2006, however, the inflection point varied among instars and regions. There was no significant trend related to inflection point. There were no significant trends that emerged when analyzing results for termination point among instars or between years. Termination point varied over years and instars. The length of linear emergence was significantly different when comparing regions over both years for each instar. Linear emergence was variable over years and instars. Emergence rates varied over years and between instars. There were no trends which emerged for this statistic.

First-, second-, and third-instar alfalfa weevils were observed in southern regions after fewer accumulated degree-days compared with central and northern regions, with the exception of first instars in 2006 (Table 1). First-, second-, and third-instar alfalfa weevils were observed in central regions after fewer accumulated degree-days compared with northern regions (Table 1).

The only significant trend that emerged in this study was time before linear emergence. The time before linear emergence occurred after fewer accumulated degree-days for first-instar alfalfa weevils in southern regions compared with northern regions for 2005 and 2006. Results found in this study confirm that Nebraska is an intermediate region, where alfalfa weevil degreeday requirements vary by latitude. Peterson and Meyer (1995) modeled the relationship between calendar dates and latitude for degree-day accumulations for alfalfa weevil egg hatch in the midwest regions, including Nebraska. Based on published research, they predicted that differences in fall ovipositional patterns in different geographical ranges would lead to differences in the timing of egg hatch and larval populations the following spring. The geographic patterns predicted by Peterson and Meyer (1995) are consistent with results found in this study.

No fourth-instar alfalfa weevils were found in samples. Early harvest, which is a beneficial management tool in Nebraska, may have caused interruptions in fourth-instar development. Sampling was also delayed $\sim 1$ wk after first cutting, at which time large larvae and cocoons were observed in alfalfa stubble and leaf litter, indicating late instars were in fact completing their life cycle.
Findings in this study are important to pest management decision-making because alfalfa weevils that emerge earlier may attack alfalfa when it is at a shorter stem height. Tolerance of alfalfa is related to its growth stage; thus, more serious damage can occur in southern regions as a result (Hintz et al. 1976). Alfalfa weevils that emerge after fewer accumulated degreedays also have more time to increase in number, causing populations to be higher in locations of lower latitude.

Alfalfa weevil density was found to vary tremendously according to latitude in this study (Stilwell 2006). Economic thresholds were determined using recommendations for Nebraska (Wedberg et al. 1977, Danielson et al. 2006) for all sampling dates in all fields sampled using an economic value of both $\$ 70$ per ton and $\$ 105$ per ton, because the economic value for alfalfa in 2006 was never below $\$ 82$ for all types of alfalfa grown in Nebraska (Barrett 2006). Only fields in central latitudes exceeded the economic thresholds. Mean number of alfalfa weevil larvae, however, was significantly higher in southern and central regions compared with northern regions (Stilwell 2006).

Although it has been determined that first-instar alfalfa weevils require fewer degree-days before emergence in southern regions compared with northern regions, data collected in this study are not able to determine whether this phenomenon was caused by variable fall and winter oviposition. More information is needed regarding fall and winter alfalfa weevil egg laying and egg survival over winter months to determine the life history strategies of the alfalfa weevil in various latitudes of Nebraska. We hypothesize that the reason alfalfa weevils require fewer degree-days before emergence at lower latitudes is likely caused by increased fall oviposition and increased overwinter egg survival. Issues related to different strains and their biology may also contribute to differences in degree-days. Ongoing research suggests the eastern strain has been replaced by the western strain of the alfalfa weevil in northern Nebraska (Erney et al. 1996).

Because of differences in degree-day requirements at varying latitudes in eastern Nebraska, the recommended time to begin scouting for alfalfa weevil larvae should vary in different regions of the state. Producers growing alfalfa in southern latitudes should begin scouting after fewer accumulated degree-days than producers growing alfalfa in northern latitudes of $\mathrm{Ne}-$ braska. Scouting offers producers the ability to determine when alfalfa weevil larvae are present and gives them adequate time to apply pest management techniques (insecticides or early cutting) if they are needed. Alfalfa growers should be aware that alfalfa weevils begin to emerge at $\approx 126$ accumulated DD in southern latitudes of Nebraska, 133 DD in central latitudes, and 155 DD in northern latitudes. Given average degree-day accumulations at this time of year in Nebraska, these accumulations represent $\sim 1$ calendar d difference between southern and central regions, an 18 calendar d difference between central and northern regions, and a 19 calendar d difference be- 
tween northern and southern regions. These estimates can be used as guidelines for sampling programs to start.

\section{Acknowledgments}

We thank L. Higley for providing a copy of the DEGDAY program for use in this research. This paper is a contribution of the University of Nebraska Agricultural Research Division, supported in part by funds provided through the Hatch Act.

\section{References Cited}

Barrett, T. 2006. Cornhusker economics. (http://www. agecon.unl.edu/Cornhuskereconomics.html).

Bartell, D. P., and S. J. Roberts. 1974. A head capsule caliper: new tool for determining instars of the alfalfa weevil. J. Econ. Entomol. 67: 801-803.

Berberet, R. C., and W. D. Hutchinson. 1994. Sampling methods for insect management in alfalfa, pp. 357-381. In L. P. Pedigo and G. D. Buntin (eds.), Handbook of sampling methods for arthropods in agriculture. CRC, Boca Raton, FL.

Brewer, M. J., and K. M. Hoff. 2002. Degree-day accumulation to time initiation of sampling for alfalfa weevil using on-site, near-site, and regional temperature data. J. Agric. Urban Entomol. 19: 141-149.

Buntin, G. D. 1994. Developing a primary sampling program, pp. 99-115. In L. P. Pedigo and G. D. Buntin (eds.), Handbook of sampling methods for arthropods in agriculture. CRC, Boca Raton, FL.

Danielson, S. D., T. E. Hunt, and K. Jarvi. 2006. Managing the alfalfa weevil. University of Nebraska-Lincoln Extension. NebGuide G208. University of Nebraska-Lincoln Extension, Lincoln, NE.

DeGooyer, T. A., L. P. Pedigo, K. L. Giles, and M. E. Rice. 1996. Phenology of the alfalfa weevil (Coleoptera: Curculionidae) in Iowa. J. Agric. Entomol. 13: 41-53.

Erney, S. J., K. P. Pruess, S. D. Danielson, and T. O. Powers. 1996. Molecular differentiation of alfalfa weevil strains (Coleoptera: Curculionidae). Ann. Entomol. Soc. Am. 89: 804-811.

Fick, G. W. 1976. Alfalfa weevil effects on regrowth of alfalfa. Agron. J. 68: 809-812.

Gibson, L. R. 2001. Growing degree-day calculation. (http:// www.agron.iastate.edu/courses/agron212/Calculations/ GDD.htm).

Giles, K. L., J. J. Obrycki, M. E. Rice, L. P. Pedigo, S. K. Barnhart, D. Hogg, T. A. DeGooyer, D. Keeney, and J. Munyaneza. 1999. Integrated pest management of alfalfa insects in the upper Midwest. Iowa State University, Ames.

Hamlin, J. C., F. V. Lieberman, R. W. Bunn, W. C. McDuffie, R. C. Newton, and L. G. Jones. 1949. Field studies of the alfalfa weevil and its environment. U.S. Dept. Agric. Tech. Bull. 975: 1-84.

Herms, D. A. 2006. Using degree-days and plant phenology to predict pest activity. In V. Krischik and J. Davidson (eds.), Tactics and tools for IPM. (http://www. entomology.umn.edu/cues/Web/094DegreeDays.pdf)

Higgins, R. A., M. E. Rice, S. L. Blodgett, and T. J. Gibb. 1991. Alfalfa stem-removal methods and their efficiency in predicting actual numbers of alfalfa weevil larvae (Coleoptera: Curculionidae). J. Econ. Entomol. 84: 650-655.

Higley, L. G., L. P. Pedigo, and K. R. Ostlie. 1986. DEGDAY: a program for calculating degree-days, and assumptions behind the degree-day approach. Environ. Entomol. 15: 999-1016.

Hintz, T. R., M. C. Wilson, and E. J. Armbrust. 1976. Impact of alfalfa weevil larval feeding on the quality and yield of first cutting alfalfa. J. Econ. Entomol. 69: 749-754.

[HPRCC] High Plains Regional Climate Center. 2006. University of Nebraska-Lincoln. (http://www.hprcc. unl.edu).

Keith, D. L., G. R. Manglitz, and W. R. Kehr. 1977. The alfalfa weevil. Nebr. Ext. Serv., Neb Guide G73-30. University of Nebraska-Lincoln Extension, Lincoln, NE.

Koehler, C. S., and G. G. Gyrisco. 1961. Responses of the alfalfa weevil Hypera postica, to controlled environments. J. Econ. Entomol. 54: 625-627.

Koehler, P. G., and D. Pimentel. 1973. Economic injury levels of the alfalfa weevil. Can. Entomol. 105: 61-74.

Kuhar, T. P., R. R. Youngman, and C. A. Laub. 2000. Alfalfa weevil (Coleoptera: Curculionidae) population dynamics and mortality factors in Virginia. Environ. Entomol. 29: $1295-1304$.

LeCato, G. L., III, and R. L. Pienkowski. 1972. High- or low-temperature treatments affecting alfalfa weevil fecundity, egg fertility, and longevity. Econ. Entomol. 65: $146-148$.

Litsinger, J. A., and J. W. Apple. 1973. Thermal requirements for embryonic and larval development of the alfalfa weevil in Wisconsin. J. Econ. Entomol. 66: 309-311.

Liu, B.W.Y., and G. W. Fick. 1975. Yield and quality losses due to alfalfa weevil. Agron. J. 67: 828-832.

Manglitz, G. R., D. L. Keith, and W. R. Kehr. 1981a. Alfalfa weevil: two strains worry Nebraska Producers. Farm, Ranch and Home Quarterly. University of Nebraska, Institute of Agriculture and Natural Resources, Lincoln, NE.

Manglitz, G. R., L. E. Klostermeyer, and D. L. Keith. 1981b. Comparisons of eastern and western strains of the alfalfa weevil in Nebraska. J. Econ. Entomol. 74: 581-588.

[NAPIS] National Agricultural Pest Information Survey: Cooperative Agriculture Pest Survey Program. 2003. Reported distribution for alfalfa weevil, Hypera postica. NAPIS-CAPS. (http:// ceris.purdue.edu/napis/pests/ aw/imap/awall.html).

Pedigo, L. P., and M. R. Zeiss. 1996. Developing a degreeday model for predicting insect development, pp. 67-74. In Analyses in insect ecology and management. Iowa State University Press, Ames, IA

Peterson, R.K.D., and S. J. Meyer. 1995. Relating degree-day accumulations to calendar dates: alfalfa weevil (Coleoptera: Curculionidae) egg hatch in the north central United States. Environ. Entomol. 24: 1404-1407.

Roberts, S. J., J. R. DeWitt, and E. J. Armbrust. 1970. Predicting spring hatch of the alfalfa weevil. J. Econ. Entomol. 63: 921-923.

SAS Institute. 2001. PROC user's manual, version 6. SAS Institute, Cary, NC.

Seymour, R. C., and K. J. Jarvi. 2002. Insects affecting Nebraska alfalfa, pp. 61-75. In A. Martin (ed.), Proceedings of the Crop Protection Clinics, 3 January 2002, Lincoln, NE. University of Nebraska-Lincoln Extension, Lincoln, NE.

Stark, J. A., R. C. Berberet, and G. W. Cuperus. 1993. Multivariate method for temporal predictions of alfalfa weevil larval populations exceeding the economic threshold in Oklahoma. Environ. Entomol. 22: 305-310.

Stark, J. A., R. C. Berberet, and G. W. Cuperus. 1994. Mortality of overwintering eggs and larvae of the alfalfa weevil in Oklahoma. Environ. Entomol. 23: 35-40. 
Stilwell, A. R. 2006. Degree-day requirements for alfalfa weevil development in eastern Nebraska and comparison of sampling techniques. MS thesis, University of Nebraska, Lincoln, NE.

Wedberg, J. L., W. G. Ruesink, E. J. Armbrust, and D. P. Bartel. 1977. Alfalfa weevil pest management program. Illinois Cooperative Extension Service Circ. 1136. University of Illinois, Champaign-Urbana.
White, C. E., E. J. Armbrust, and J. Ashley. 1972. Crossmating studies of eastern and western stains of alfalfa weevil. J. Econ. Entomol. 65: 85-89.

Yakhontov, V. V. 1974. The alfalfa weevil or Phytonomus. Indian National Scientific Documentation Centre, New Delhi, India.

Received 12 February 2009; accepted 15 October 2009. 